\title{
Meta Analysis: Effect Of Dental Service Quality On Patient Satisfaction In Health Facilities
}

\author{
Firda Amelia ${ }^{1}$, Edi Hartoyo ${ }^{2}$, Rosihan Adhani ${ }^{3}$, \\ Husaini $^{3}$, Meitria Syahadatina Noor ${ }^{3}$ \\ ${ }^{1}$ Master of Public Health Study Program, Faculty of Medicine, Lambung Mangkurat University \\ ${ }^{2}$ Faculty of Medicine, Lambung Mangkurat University \\ ${ }^{3}$ Faculty of Dentistry, Lambung Mangkurat University \\ DOI: 10.29322/IJSRP.11.07.2021.p11526 \\ http://dx.doi.org/10.29322/IJSRP.11.07.2021.p11526
}

\begin{abstract}
Background:Indonesian society has a high level of dental and oral health problems. Based on health seeking behavior data, as many as $57.6 \%$ of the community complained of dental and oral problems, but only $12.3 \%$ received treatment and care from dental health workers, while $56.6 \%$ others did self-medication. The results of the 2018 Community Satisfaction Survey (SKM) stated that the level of community satisfaction in obtaining medical services was still low (Menti Yolanda, 2018). Around $87 \%$ of the people still stated that they were not satisfied. Overall affordability to get services from dental medical personnel (Effective Medical Demand/EMD) is only $8.4 \%$ and of $8.4 \%$ of patients who seek treatment, $87 \%$ of patients complain of being dissatisfied with the services provided (Kemenkes RI, 2018).
\end{abstract}

Aim: Knowing the tendency of the influence of the quality of dental and oral health services seen from the dimensions of physical evidence, reliability, responsiveness, assurance and empathy for patient satisfaction in health facilities.

Method:This study uses a meta-analysis method with a crosssectional design and uses the research gate search method on the pubmed, sinta and garuda databases. The results of the identification after going through the selection stage obtained 10 journals that match the inclusion criteria. Statistical test using Revman 5.4.

Result: 5 dimensions have a weak influence on patient satisfaction with the results of physical evidence POR 0.70; CI = $0.39-1.27 ; \mathrm{Z}=1.17$, POR reliability $0.78 ; \mathrm{CI}=0.49-1.25$; $\mathrm{Z}=1.02$, Responsiveness POR $1.12 ; \mathrm{CI}=0.68-1.85 ; \mathrm{Z}=0.65$, Assurance POR $0.99 ; \mathrm{CI}=0.44-2.23 ; \mathrm{Z}=0.02$ and Empathy POR $0.87 ; \mathrm{CI}=0.41-1.18 ; \mathrm{Z}=0.38$.

Conclusion: The quality of dental health services in terms of 5 dimensions of servqual has a weak influence on variable

\section{Index Terms- quality of health services, patient satisfaction, dimensions of satisfaction, dental and oral services}

\section{INTRODUCTION}

$\mathrm{I}$ Indonesia is one of the developing countries with low dental and oral health status. The 2018 National RISKESDAS data states that as many as $57.6 \%$ of Indonesians have dental and oral health problems. This is still far from the Ministry of Health's target of the 2030 Caries-free Indonesia Strategic Plan. Based on the results of the 2018 RISKESDAS, as many as $57.6 \%$ of Indonesians have dental and oral problems, of which only 12.3 health seeking behavior is available \% who received treatment and care from dental health personnel, while the other $56.6 \%$ did self-medication. Overall affordability to get services from dental medical personnel (Effective Medical Demand/EMD) is only 8.4\%. \% (Ministry of Health RI, 2018).

The results of the analysis of the Riskesdas data show that many people are afraid to visit health care facilities, especially dental and oral health services because of various factors such as the high cost of services, the length of time needed while waiting for services, it takes several visits for treatment, treatment actions that feel painful , medical staff who are less friendly and so on which makes patients feel less satisfied in performing treatment (Dewanto, 2014).

Based on the Minister of Health Regulation No. 89 of 2015 concerning efforts to improve the quality of dental and oral services in order to reduce the prevalence of caries has not been achieved. This is evidenced by the results of the 2018 Community Satisfaction Survey (SKM) regarding dental health services in Indonesian health facilities stating that the level of community satisfaction in obtaining medical services is still low (Imelda et al, 2019). Around $87 \%$ of the community still stated that they were not satisfied with the dental health services they received, especially the problem of waiting time and the length of treatment visits (Meutia Dewi, 2016).

Based on several studies, the results of policy evaluations and the value of the community satisfaction survey above the patient dissatisfaction rate are still high, more than $35 \%$ in various studies stating that they are not satisfied with the services provided (Riskesdas, 2018). The high number of community dissatisfaction (> 35\%) with the quality of services obtained so that the caries prevalence rate is still high $(57.6 \%)$ and the level of visits to health facilities is still low (12.3\%). From the articles obtained (Kemenkes RI, 2018), 6 articles state that service quality in 5 aspects has an influence on dental and oral patient satisfaction. Meanwhile, 4 other articles stated that not all aspects of service quality have an influence on dental and oral patient satisfaction.

This publication is licensed under Creative Commons Attribution CC BY. 
ISSN 2250-3153

The facts of this research gap make prospective researchers interested in mapping research results related to the level of satisfaction of dental health services in health facilities, so that a new study with a large number of subjects can be drawn so that more definitive conclusions can be drawn.

\section{Study Design}

\section{RESEARCH METHOD}

The research design used is a Systematic Literature Review with a Meta Analysis research design. Meta-analysis is a form of research, using data from other existing studies (secondary data) with quantitative methods.

\section{Subject}

The data search refers to the data base sources, namely Google Scholar, Pubmed and Garuda Portal which are adjusted to the research title. The keywords used to search the article were "service quality, dental and oral health, patient satisfaction, servqual method, service dimensions, dimensions of physical evidence, reliability, responsiveness, assurance, empathy, service quality, oral and dental health, patient satisfaction, servqual. method, tangible, reliability, responsiveness, assurance, and empathy".

\section{Data analysis}

The literature search and selection process is described in the form of a Flow diagram of Preferred Reporting Items for Systematic Reviews and Meta-analyses (PRISMA). Synthesis of data using SPIDER (Sample, Phenomenon of Interest, Design, Evaluation, Research type). Data quality analysis was performed using the Duffy's Research Appraisal Checklist Approach table. Statistical analysis using Revman 5.4. using heterogeneity test and random effect model (REM). The results of this software are Forest plots and funnel plots.

\section{FINDINGS}

Based on the prism diagram, 1207 articles were found about the relationship between service quality and the level of satisfaction of dental and oral patients in health facilities, then screening was carried out according to inclusion criteria, 23 articles were found. After reviewing the journals that meet the requirements for statistical tests, 10 articles are obtained to be analyzed.

The relationship between the quality of health services in terms of physical evidence (tangible) on the satisfaction of dental patients in health facilities

Based on Figure 1, the results of the heterogeneity test analysis are very high $(\mathrm{I} 2=95 \%)$ so that the data analysis uses Random Effect Models. The results of statistical tests obtained the number Pooled Odds Ratio $(\mathrm{POR})=0.70 ; 95 \% \mathrm{CI}=0.39-1.27$; the overall effect value $\mathrm{Z}=1.17$. These results indicate that the quality of dental and oral health services on the aspect of physical evidence (tangibles) has a weak effect (POR <3) on patient satisfaction.

Based on Figure 3, the results of the funnel plot show that there is publication bias indicated by the asymmetry of the plots on the right and left of the vertical line where the distance between the plots is not the same and there are 4 plots on the left of the vertical line and 6 plots on the right where one of them touches the vertical line.

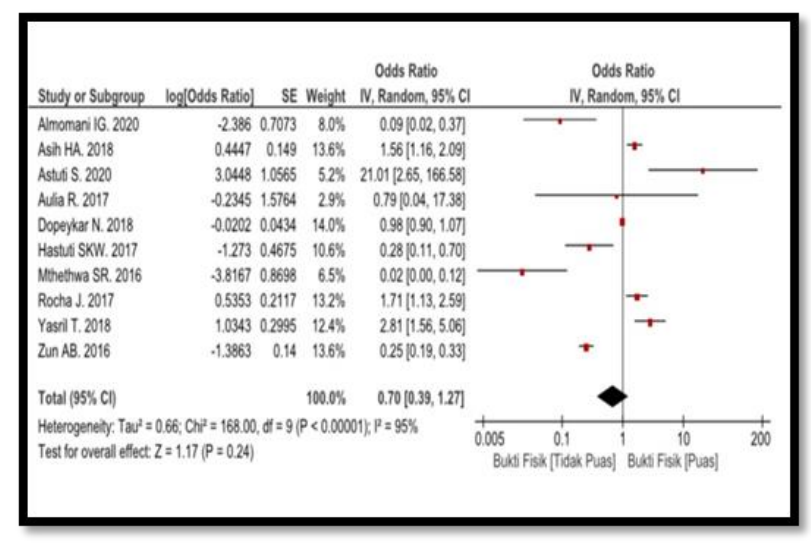

Figure 1. Forest Plot Physical Evidence 


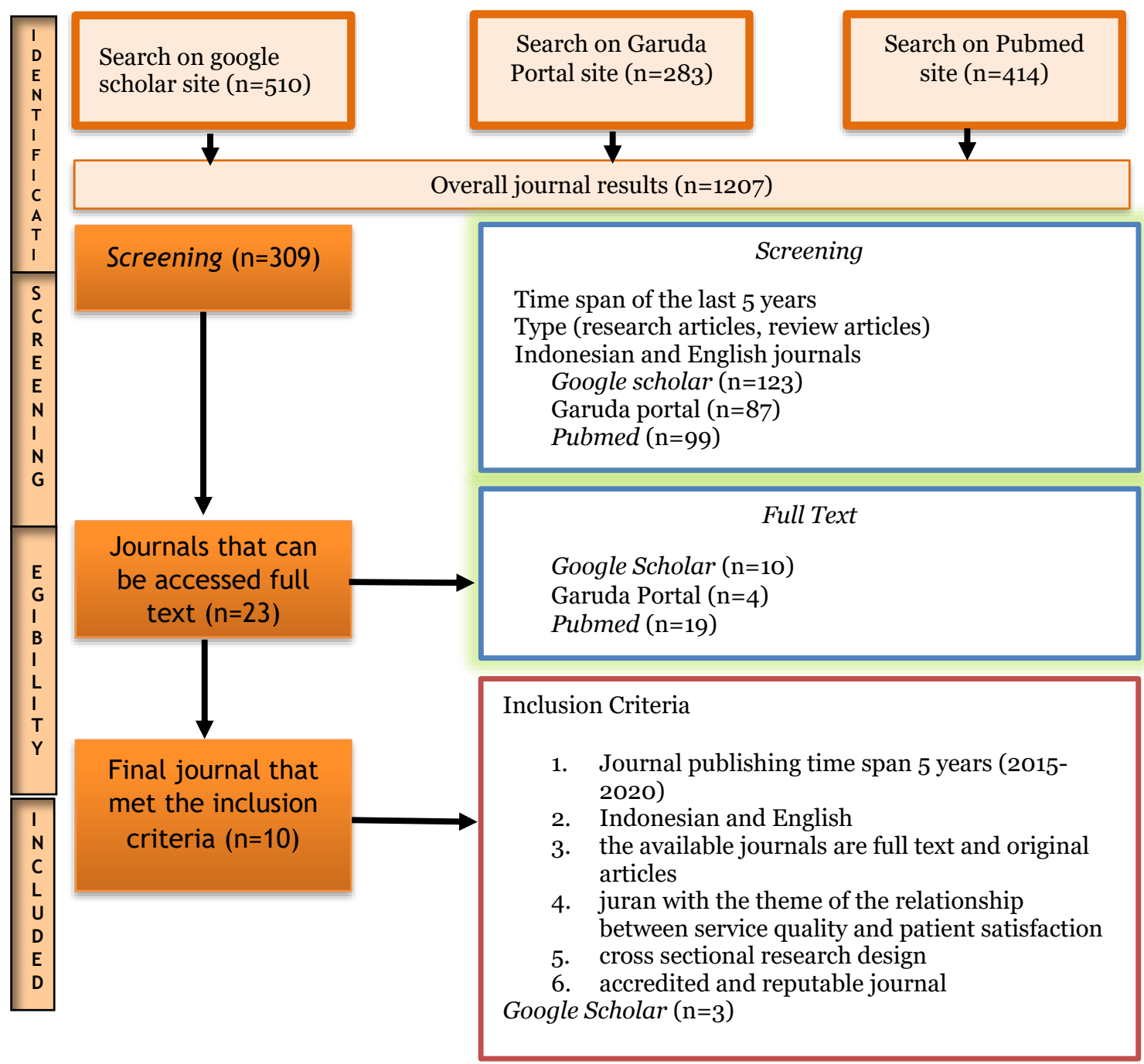

Figure 2. Prism Diagram

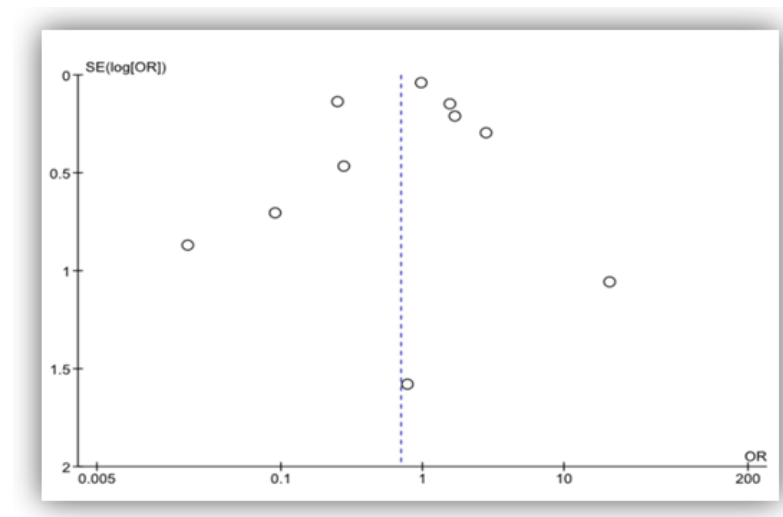

Figure 3. Funnel Plot Physical Evidence

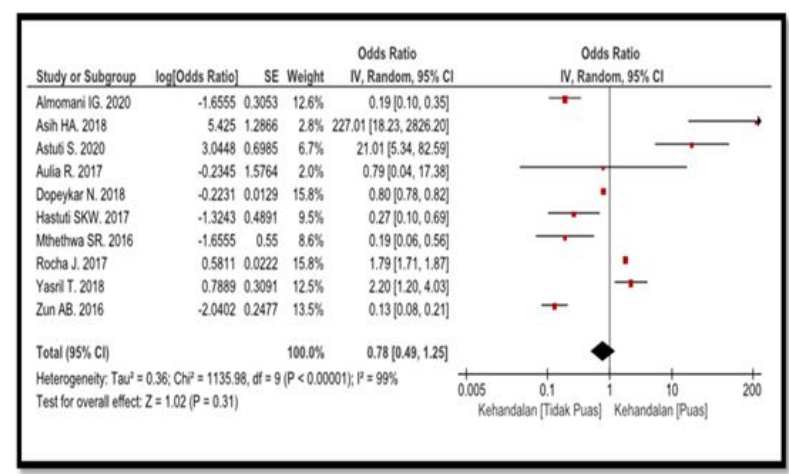

Figure 4. Forest Plot Reliability

The relationship between the quality of health services in terms of the dimension of reliability (Reliability) on the satisfaction of dental patients in health facilities. 


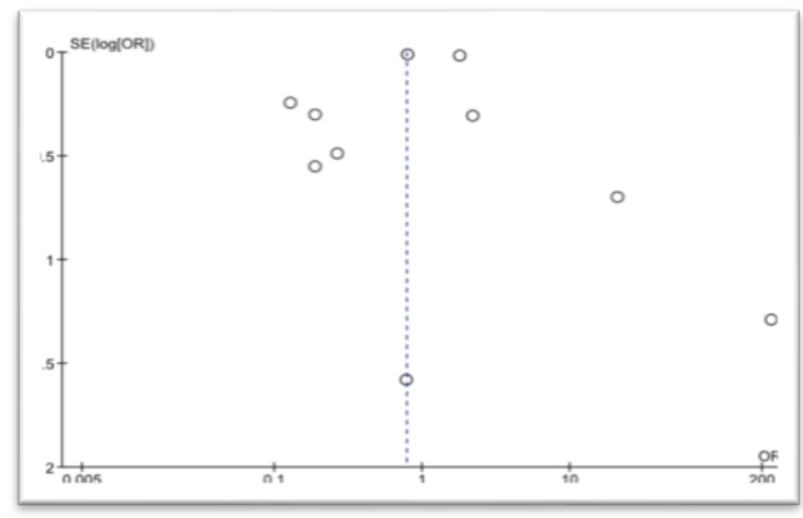

Figure 5. Funnel Plot Reliability

Based on Figure 4. shows the results of the heterogeneity test analysis are very high $(\mathrm{I} 2=99 \%)$ so that the data analysis uses Random Effect Models. The results of statistical tests obtained POR $=0.78 ; 95 \% \mathrm{CI}=0.49$ to 1.25 ; the overall effect value $\mathrm{Z}=$ $1.02 \mathrm{P}=0.31$. These results indicate that reliability has a weak effect $(\mathrm{POR}<3$ ) on patient satisfaction.

Based on Figure 6. The results of the funnel plot show that there is a publication bias marked by the asymmetry of the plots on the right and left of the vertical line where the distance between the plots is not the same and there are 4 plots on the left and right of the vertical line and 2 plots that touch the vertical line.

The relationship between the quality of health services is viewed from the Responsiveness Dimension to the satisfaction of dental patients in health facilities.

The results of statistical tests obtained POR $=1.12 ; 95 \% \mathrm{CI}=$ 0.68 to 1.85 ; the overall effect value $\mathrm{Z}=0.46 \mathrm{P}=0.65$. These results indicate that the responsiveness dimension has a weak effect $(\mathrm{POR}<3)$ on patient satisfaction.

Based on Figure 8. the results of the funnel plot show that there is a publication bias marked by unbalanced and asymmetrical plots on the right and left of the vertical line where the distance between plots is not the same and there are 6 plots on the left of the vertical line and 4 plots on the right

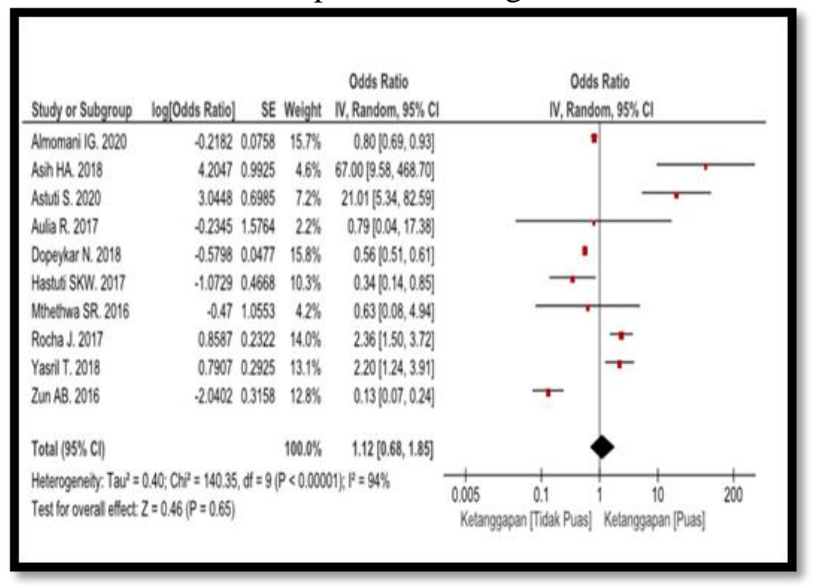

Figure 7. Forest Plot Response

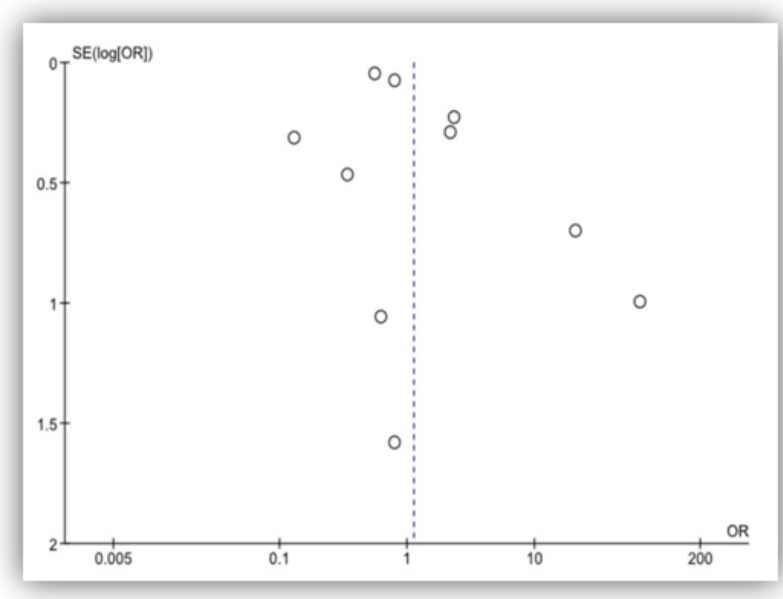

Figure 8. Funnel Plot Response

The relationship between the quality of health services in terms of the Assurance Dimension on the satisfaction of dental patients in health facilities

Based on Figure 9. shows the results of the heterogeneity test analysis are very high $(\mathrm{I} 2=99 \%)$ so that the data analysis uses Random Effect Models. The results of statistical tests obtained $\mathrm{POR}=0.99 ; 95 \% \mathrm{CI}=0.44$ to 2.23 ; the overall effect value $\mathrm{Z}=$ $0.02 \mathrm{P}=0.6$ The results show that assurance has a weak effect $(\mathrm{POR}<3)$ on patient satisfaction.

Based on Figure 10. The results of the funnel plot show that there is publication bias marked by unbalanced and asymmetrical plots on the right and left of the vertical line where the distance between plots is not the same and there are 6 plots on the left of the vertical line and 4 plots on the right.

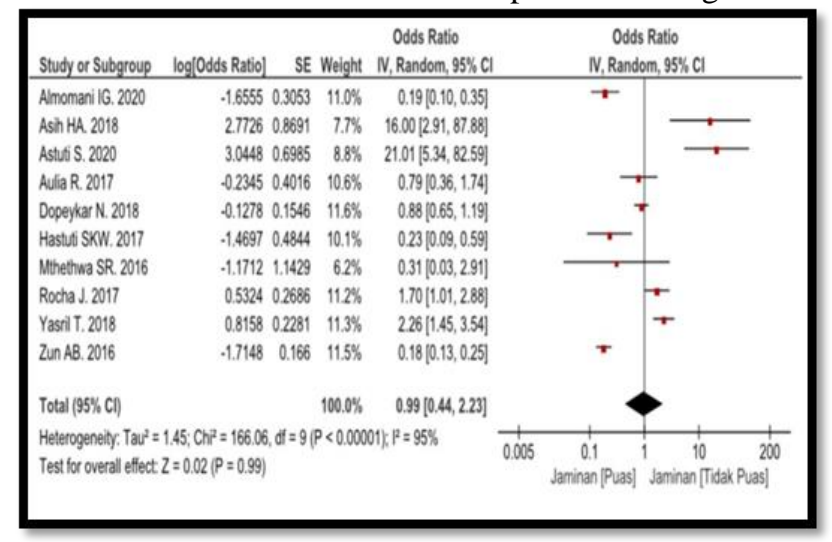

Figure 9. Forest Plot Guarantee

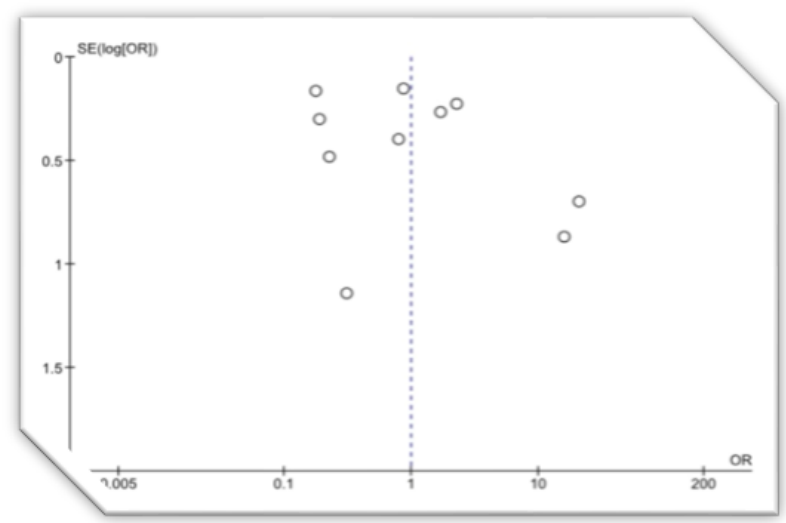


Figure 10. Funnel Plot Guarantee

The relationship between the quality of health services in terms of the Empathy Dimension on the satisfaction of dental patients in health facilities

Based on Figure 11. shows the results of the heterogeneity test analysis are very high $(\mathrm{I} 2=91 \%)$ so that the data analysis uses Random Effect Models. Statistical test results obtained POR = $0.87 ; 95 \% \mathrm{CI}=0.41$ to 1.18 ; the overall effect value $\mathrm{Z}=0.38$ $\mathrm{P}=0.70$ The results show that empathy has a weak effect $(\mathrm{POR}<3)$ on patient satisfaction.

Based on Figure 12. The results of the funnel plot show that there is almost no publication bias marked by a balanced number of plots on the left and right sides of the vertical line and forms an almost symmetrical picture where the distance between plots is almost the same and there are plots on the left and right of the vertical and 4 plots touch the vertical line.

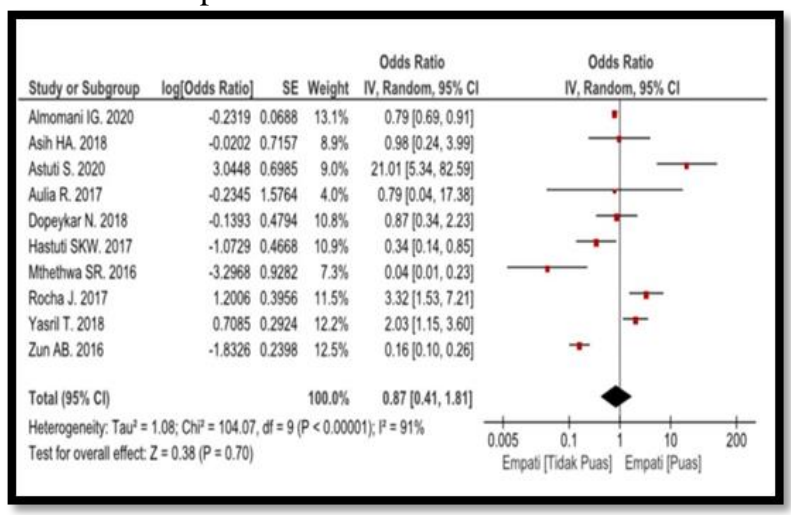

Figure 11. Forest Plot Empathy

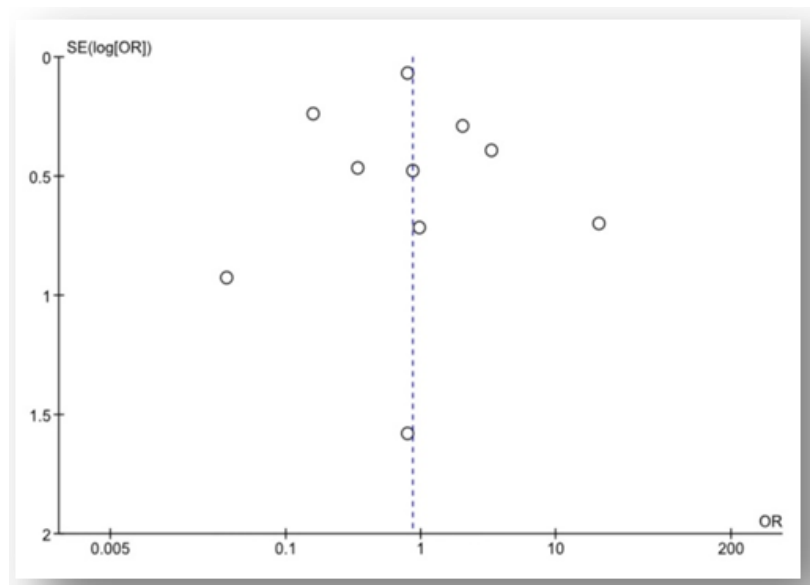

Figure 12. Empathy Funnel Plot

\section{DISCUSSION}

The effect of the quality of health services on the dimensions of physical evidence on patient satisfaction

Based on 10 journals that have been analyzed, the results of the combined effect conclude that the quality of dental health services in terms of the dimensions of physical evidence (tangible) on patient satisfaction has a pOR value $=0.70$ and a $95 \%$ confidence interval ( 0.39 to 1.27$)$. The range of pOR strength is between the number 0.7 , which means it has a weak relationship level. It can be concluded that the quality of dental health services in terms of the physical evidence dimension (tangible) has a weak influence on patient satisfaction, where the physical evidence dimension (tangible) has a tendency to increase 0.70 times for patients to feel satisfied and want to visit again.

The results showed that the dimensions of physical evidence had a weak effect on patient satisfaction. This means that the neatness or completeness of the examination room is good, comfort, appearance of dental health workers who are neat and clean, the cleanliness of the waiting room, completeness of facilities, the tranquility of the examination room and the availability of toilets and a neat parking area have an influence on patient satisfaction/dissatisfaction. During the current COVID-19 pandemic, physical appearances such as the use of Level 3 PPE in the form of hazmats, boots, headcaps, face shields, handschoons and masks by dentists and nurses also have an influence on patient trust and satisfaction in getting health services. The more complete the PPE, the patient will feel more calm and comfortable (Imelda et al, 2019). This is in line with other studies, which states that the convenience of service facilities is not related to clinical effectiveness, but can affect patient satisfaction and willingness to return to health facilities to obtain the next service. Patient satisfaction depends on physical evidence contained in health facilities, the better the physical evidence displayed, the higher patient satisfaction will be obtained or vice versa (Kurnia, et al 2017)

The effect of the quality of health services on the dimensions of reliability on patient satisfaction

Based on 10 journals that have been analyzed, the results of the combined effect conclude that the quality of dental health services in terms of reliability to patient satisfaction has a pOR value $=0.78$ and a $95 \%$ confidence interval $(0.49$ to 1.25$)$. The range of pOR strength is between 0.78 , which means it has a weak relationship level. It can be concluded that the quality of dental health services in terms of the reliability dimension has a weak but weak influence on patient satisfaction, where the reliability dimension has a tendency to increase 0.78 times for patients to feel satisfied and want to make return visits (Kurnia, et al 2017).

These results indicate that patient admission procedures, service procedures, clinic card opening hours and arrival hours of dental health workers will affect patient satisfaction. During the COVID-19 pandemic, the online patient registration procedure was considered more satisfying for patients because the waiting time was not long, there were no crowds and came directly to get services. The results of this study are supported by the results of research conducted by Ridha, et al. (2017) which states that there is a positive influence between reliability and patient satisfaction. A good level of service is able to provide services immediately, accurately (accurately) and satisfactorily, which reflects consistency and reliability. If the service has not been able to satisfy the patient this will end in low satisfaction itself. Consistent service is most desired by patients in the sense that the service must be reliable. Consistent service is a reliable service that contains elements of doing what has been promised to patients, being professional in serving patients and being accurate in providing information to patients. If this can be given 
to patients, it will increase service satisfaction for patients (Ridha et al, 2017).

\section{The effect of the quality of health services on the dimensions of responsiveness on patient satisfaction}

Based on 10 journals that have been analyzed, the results of the combined effect conclude that the quality of dental health services in terms of responsiveness to patient satisfaction has a pOR value of 1.12 and a confidence interval of $94 \%$ (0.68 to $1.85)$. The range of pOR strength is between 1.12 , meaning that it has a weak relationship level. It can be concluded that the quality of dental health services in terms of responsiveness has an influence but is weak on patient satisfaction, where responsiveness has a tendency to increase 1.12 times for patients to feel satisfied and want to make return visits.

The results of this study are supported by the results of research conducted by Fryanantha (2014), namely there is an influence between the responsiveness of officers and the realization of the quality of health services where officers who have high responsiveness will increase patient satisfaction with the services provided (Boy Suzanto, 2018). Responsiveness is a willingness to help and provide fast and appropriate service to patients and the delivery of information. In addition, during the COVID-19 pandemic, apart from providing direct explanations and consultations, when patients return home, they can still consult with doctors who serve patients at the clinic, such as teledentistry. This makes the patient feel free to have a private consultation with a relaxed time.

The results of this study are supported by the results of research conducted by Fryanantha (2014), namely there is an influence between the responsiveness of officers and the realization of the quality of health services where officers who have high responsiveness will increase patient satisfaction with the services provided.

Responsiveness is a willingness to help and provide fast and appropriate service to patients and the delivery of information. In Cahyadi's research, there are several indicators of responsiveness, including paramedics who are always ready to help patients, patients do not wait long to get services, paramedics are very easy when asked for help, paramedics do not discriminate between patients in providing services and paramedics tell patients if they are going to take an action (Kurnia, 2010). et al 2017).

\section{The effect of the quality of health services on the dimensions of assurance on patient satisfaction}

Based on 10 journals that have been analyzed, the results of the combined effect conclude that the quality of dental health services in terms of the assurance dimension to patient satisfaction has a pOR value $=0.99$ and a $95 \%$ confidence interval ( 0.44 to 2.23$)$. The range of pOR strength is between 0.99 , meaning that it has a weak relationship level. It can be concluded that the quality of dental health services in terms of the assurance dimension has a weak but weak effect on patient satisfaction, where assurance has a tendency to increase 0.99 times for patients to feel satisfied and want to make return visits. The results of this study are supported by the opinion of Kotler in Febriani (2018), defining guarantee is knowledge of the right product, politeness of employees in providing services, the This publication is licensed under Creative Commons Attribution CC BY. ability to instill trust and convince customers of the services provided. The assurance dimension includes knowledge, ability, courtesy, and trustworthiness possessed by health care providers, free from risks and dangers or patient doubts (Febriani et al, 2018). If the guarantee for the quality of services received or perceived is lower than expected, then the quality of health services will be perceived as bad or unsatisfactory. In addition, in the current covid-19 pandemic, guarantees for patients to feel safe doing dental treatment are very important. The presence of a specially designed room to avoid air born and transmission such as the use of extra oral suction and an air purifier and UV light is considered to be able to improve the quality and confidence of the patient. Therefore, whether or not the quality of service depends on the ability of service providers to consistently meet patient expectations (Kurnia, et al 2017).

\section{The effect of the quality of health services on the dimensions of empathy on patient satisfaction}

Based on 10 journals that have been analyzed, the results of the combined effect concluded that the quality of dental health services in terms of the empathy dimension to patient satisfaction has a pOR $=0.87$ and a confidence interval of $91 \%$ ( 0.41 to 1.18$)$. The range of pOR strength is between 0.87 , which means that it has a weak relationship. It can be concluded that the quality of dental health services in terms of the dimensions of empathy (Empathy)) has a weak influence on patient satisfaction, where empathy (Empathy) has a tendency to increase 0.99 times for patients to feel satisfied and want to make return visits.

Empathy (attention) of officers in this study is the perception of the respondent's or patient's assessment of the quality of service seen from the treatment given by health care workers in making relationships, good communication, attention to patients and understanding patient needs. Empathy is giving sincere and individual or personal attention given to patients by trying to help their wishes (Aulia, 2017). This shows that the attitude of attention of dental health workers in listening to patient complaints, services that do not distinguish the patient's social status and the communication that exists between patients and dentists is good, resulting in satisfaction for patients who receive services Empathy for health services according to Aditama (2018), One of the health services is establishing good relations with the patient's family because it can help accelerate the patient's healing (Wahyu Kuntoro, 2017).

The ability to provide quality services on the empathy variable is a personal interpretation of doctors/nurses having a good desire in providing services to patients. This of course will directly provide positive benefits for hospitals in building better relationships with patients. Empathy of health workers is related to patient satisfaction, empathy is the attention of officers in understanding patient needs. The attitude of officers who are patient, diligent, and reassuring in providing health services to patients (Kurnia, et al 2017).

\section{CONCLUSION}

Based on the results of meta-analysis and data synthesis from previous research articles that match the inclusion criteria, it can be concluded that: 
1. The dimension of physical evidence (tangible) has a weak influence on patient satisfaction in health facilities, that physical evidence increases patient satisfaction 0.70 times for repeat visits to dental health facilities.

2. The reliability dimension has a weak influence on patient satisfaction in health facilities, that reliability increases patient satisfaction 0.78 times for repeat visits to dental health facilities.

3. The responsiveness dimension has a weak influence on patient satisfaction in health facilities, that responsiveness increases patient satisfaction 1.12 times for repeat visits to dental health facilities.

4. The assurance dimension has a weak effect on patient satisfaction in health facilities, that assurance increases patient satisfaction 0.99 times for repeat visits to dental health facilities.

5. The dimension of empathy (empathy) has a weak influence on satisfaction. patients in health facilities, that guarantees increase patient satisfaction 0.87 times to make repeat visits to dental health facilities.

6. The quality of dental and oral health services in 5 aspects of servqual has a weak influence on patient satisfaction in health facilities.

7. Of the 5 dimensions studied, the responsiveness dimension has the greatest influence with a value of 1.12 times to increase patient repeat visits to health facilities.

\section{REFERENCES}

Aulia R, dkk. Pengaruh kualitas pelayanan kesehatan gigi dan mulut terhadap kepuasan pasien BPJS di layanan primer Banjarmasin. Dentino (Jur. Ked. Gigi), Vol II. No 1. Maret 2017 : 95- 100.

Boy Suzanto. Pengaruh Kualitas Jasa Pelayanan Terhadap Kepuasan Pasien Pada Rumah Sakit Umum Kota Banjar. Jurnal Ekonomi, Bisnis \& Entrepreneurship Vol. 5, No. 1, April 2018, 28-44

Dewanto I, Lestari NI. Pedoman Pelaksanaan Program Jaminan Kesehatan Nasional. Panduan Pelaksanaan Pelayanan Kedokteran Gigi Dalam. Jakarta : PB PDGI 2014

Gunawan S, Dkk,. Pengukuran Kepuasan Pasien Rawat-Inap Rumah Sakit Umum Daerah Tarakan Jakarta. Jurnal Bakti Masyarakat Indonesia. Vol. 1, No. 1, Mei 2018, Hal. 153159

Hunter, J. E., Jensen, J. L., \& Rodgers, R. The Control Group and Meta-Analysis. Journal of Methods and Measurement in the Social Science, 2014, 5(1), 3-21.

Ida Ayu I.S, dkk. Tingkat kepuasan pasien peserta JKN terhadap kualitas pelayanan kesehatan gigi dan mulut di Poliklinik Gigi Puskesmas 1 Denpasar Timur. BDJ, Volume 2, Nomor 1, Januari - Juni 2018: 31-36.

Ibrahim, Dkk. Tingkat Kepuasan Pasien Terhadap Pelayanan Kesehatan Gigi Dan Mulut. Jurnal Ilmiah Kesehatan Iqra. Volume 6 Nomor 1 Bulan Juli Tahun 2018

I Gede Yogi Darma, Dkk. Gambaran Tingkat Kepuasan Pasien Terhadap Kualitas Pelayanan Kesehatan Di Poliklinik Gigi Dan Mulut Rumah Sakit Umum Puri Raharja. Odonto Dental Journal. Volume 5. Nomer 1. Juli 2018

I Gusti Ayu Sri Wulan W, dkk. Gambaran tingkat kepuasan pasien peserta BPJS dan pasien umum terhadap This publication is licensed under Creative Commons Attribution CC BY. http://dx.doi.org/10.29322/IJSRP.11.07.2021.p11526 pelayanan di faskes tingkat pertama poli gigi Puskesmas IV Denpasar Selatan. BDJ, Volume 3, Nomor 2, JuliDesember 2019: 64-69, e-ISSN: 2549-0109.

Imelda, dkk. Memastikan Keberlangsungan JKN-KIS untuk Masyarakat Indonesia. Deloitte Indonesia Perspectives Edisi Pertama, September 2019.

Kemenkes RI. Laporan hasil riset kesehatan dasar Nasional tahun 2013. Jakarta : Kementrian Kesehatan, 2013.

Kemenkes RI. Laporan hasil riset kesehatan dasar Nasional tahun 2013. Jakarta : Kementrian Kesehatan, 2018.

Mansyur dan Akbar Iskandar. Meta Analisis Karya Ilmiah Mahasiswa Penelitian Dan Evaluasi Pendidikan. Jurnal Scientific Pinisi, Volume 3, Nomor 1, April 2017, Hlm. $72-79$

Menti Youlanda. Kualitas Pelayanan Kesehatan Poli Gigi Rumah Sakit Kota Palembang. MBIA, Vol. 17, No. 3, Desember 2018, ISSN 2086-5090.

Meutia Dewi. Pengaruh Kualitas Pelayanan Terhadap Kepuasan Pasien Pengguna Bpjs Pada Rumah Sakit Rehabilitasi Medik Kabupaten Aceh Timur. Jurnal Manajemen Dan Keuangan, Vol.5, No.2, November 2016

Munawir. Persepsi Kualitas Layanan dan Kepuasan Pelanggan pada Pusat Perbelanjaan Kota Banda Aceh dengan Metode SERVQUAL. Jurnal Ekonomi dan Manajemen Teknologi, 2(1), 2018, 1-54

Nieuwenstein, et al. On making the right choice: A metaanalysis and large-scale replication attempt of the unconscious thought advantage. Judgment and Decision Making, 2015., 10(1), 1-17.

Noor Hafida Widyastuti, dkk. Pengaruh Kualitas Pelayanan Konservasi Gigi Terhadap Kepuasan Pasien Bpjs Di Fasilitas Kesehatan Tingkat Pertama Kota Surakarta (Kajian di Puskesmas Gajahan). The 11th University Research Colloquium 2020 Universitas 'Aisyiyah Yogyakarta

Paldam, M. Meta-Analysis in a Nutshell: Techniques and General Findings MetaAnalysis in a Nutshell : Techniques and General Findings. Economics: The OpenAccess, Open-Assessment E-Journal, 2015), 1-14.

Permenpan. Pedoman Penyusunan Survei Kepuasan Masyarakat Unit Penyelenggara Pelayanan Publik. Peraturan Menteri Pendayagunaan Aparatur Negara Dan Reformasi Birokrasi Republik Indonesia Nomor 14 Tahun 2017

Sunarti, D.A.A. Pengaruh Kualitas Pelayanan Terhadap Kepuasan Konsumen (Survei Pada Konsumen The Little A Coffee Shop Sidoarjo). Jurnal Administrasi Bisnis (Jab)|Vol. 51 No. 2 Oktober 2017.

Sutinah E , Simamora O.R. Metode Fuzzy Servqual Dalam Mengukur Kepuasan Pasien Terhadap Kualitas Layanan Bpjs Kesehatan. Jurnal Informatika, Vol.5 No.1 April 2018, Pp. 90-101

Wahyu Kuntoro, Wahyudi Istiono. Kepuasan Pasien Terhadap Kualitas Pelayanan di Tempat Pendaftaran Pasien Rawat Jalan Puskesmas Kretek Bantul Yogyakarta. Jkesvo (Jurnal Kesehatan Vokasional) Vol. 2 No 1 - Mei 2017

Wahyu Kurniawati, Riris Diana Rachmayanti. The Identification Causes JKN',s Low Membership at Informal Sector in Rural Areas. Jurnal Administrasi Kesehatan Indonesia Volume 6 Nomor 1, Januari - Juni 2018. 
International Journal of Scientific and Research Publications, Volume 11, Issue 7, July 2021 